\title{
Inovasi Sistem Stack Microbial Fuel Cell menggunakan Substrat Limbah Rumen Sapi serta Implementasinya sebagai Media Pembelajaran
}

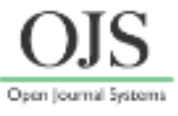

\author{
Diya Novarina ${ }^{1,2^{*}}$, Eko Swistoro ${ }^{3}$, M. Lutfi Firdaus ${ }^{1}$ dan Rosane Medriati ${ }^{3}$ \\ ${ }^{1}$ Pascasarjana Pendidikan IPA, FKIP Universitas Bengkulu \\ ${ }^{2}$ SMA Muhammadiyah 4 Kota Bengkulu \\ ${ }^{3}$ Pendidikan Fisika, FKIP Universitas Bengkulu \\ *Email: diyanovarina@gmail.com
}

\begin{abstract}
[Innovation of microbial fuel cell stack system using cow rumen waste substrate and its implementation as a learning media]. The aims of this study are to: 1) describe the difference of Electric Motion (GGL), 2) describe the difference of electric power per unit area of the anode $(\mathrm{Pa})$ which is produced between the series design MFC type series, parallel, mixed type 1 and mixed type 2, and 3) describe the significant difference of learning outcomes between the PBL learning model using MFC media with PBL learning model by using the electrical kit medium on dynamic electrical concept in SMA Muhammadiyah 4 Bengkulu. The free variable of this research are MFC stack system design (series, parallel, mixed types 1 and 2) and the dependent variable is GGL and electric power per unit of anode surface area. The results are obtained difference GGL and Pa between series design, parallel, mixed types 1 and 2 by comparison are 3: 1: 1,5: 2 whereas Pa ratio is 1: 10: 6: 2 with maximum GGL is obtained in series design of 3,29 V and Pa maximum in parallel circuit 21,76 $\mathrm{mW} / \mathrm{m}^{2}$. Implementation of MFC series as a learning media used Problem Based Learning model on physics learning Implementation of MFC circuit with research design using one group pretest-posttest design. The testing of hypothesis with t-test shows $t_{\text {count }} 2.739>t_{\text {table }} 2,001$ and $95 \%$ significant level so it can be concluded there are significant differences in learning outcomes of PBL learning model by using MFC media with PBL learning model by using media Electric Kit on dynamic electrical concept in SMA Muhammadiyah 4 Bengkulu.
\end{abstract}

Keywords: Stack Microbial Fuel Cell (MFC) Sistem; Rumen Cow Liquid Waste; Learning Media.

\begin{abstract}
ABSTRAK
Penelitian ini bertujuan untuk: 1) menjelaskan perbedaan Gaya Gerak Listrik (GGL), 2) menjelaskan perbedaan daya listrik per satuan luas anoda $(\mathrm{Pa})$ yang dihasilkan antara disain rangkaian MFC tipe seri, paralel, campuran tipe 1 dan campuran tipe 2, dan 3) menjelaskan perbedaan hasil belajar yang signifikan antara pembelajaran model PBL menggunakan media MFC dengan pembelajaran model PBL menggunakan media kit listrik pada konsep listrik dinamis di SMA Muhammadiyah 4 Kota Bengkulu. Penelitian sains merupakan penelitian eksperimen dengan variabel bebas adalah disain sistem stack MFC (rangkaian tipe seri, paralel, campuran tipe 1 dan 2) serta variabel terikat adalah GGL dan daya listrik per satuan luas permukaan anoda. Hasil penelitian yang diperoleh antara lain terdapat perbedaan GGL dan Pa antara disain rangkaian seri, paralel, campuran tipe 1 dan 2 dengan perbandingan 3:1:1,5:2 sedangkan perbandingan $\mathrm{Pa}$ adalah 1:10:6:2 dengan GGL maksimum diperoleh pada rangkaian seri sebesar 3,29 V dan Pa maksimum pada rangkaian paralel $21,76 \mathrm{~mW} / \mathrm{m}^{2}$. Implementasi rangkaian MFC sebagai media pembelajaran menggunakan model Problem Based Learning dengan disain penelitian menggunakan one group pretestposttest design. Pengujian hipotesis dengan uji-t menunjukkan $t_{\text {hitung }} 2,739>t_{\text {tabel }} 2,001$ dan taraf signifikan 95\% sehingga dapat disimpulkan terdapat perbedaan hasil belajar yang signifikan antara pembelajaran model PBL menggunakan media MFC dengan pembelajaran model PBL menggunakan media kit listrik pada konsep listrik dinamis di SMA Muhammadiyah 4 Kota Bengkulu.
\end{abstract}

Kata Kunci: Sistem Stack Microbial Fuel Cell (MFC); Limbah Rumen Sapi; Media Pembelajaran. 


\section{PENDAHULUAN}

Energi listrik telah menjadi bagian yang tidak dapat dipisahkan dari kebutuhan hidup masyarakat seperti kebutuhan rumah tangga, industri, kesehatan, pendidikan dan lain-lain. Namun pelaksanaan penyediaan energi listrik yang dilakukan oleh PT.PLN (Persero) sampai saat ini masih belum dapat memenuhi kebutuhan masyarakat secara keseluruhan. Krisis energi listrik ini memicu pengembangan sumber energi alternatif ramah lingkungan dan untuk mengganti penggunaan minyak bumi. Salah satu energi alternatif yang ramah lingkungan adalah Microbial Fuel Cell (MFC). Zhang (2012) menyatakan MFC adalah bioelektrokimimia yang dapat mengkonversi energi kimia yang tersimpan dalam limbah materi organik atau biomassa menjadi listrik dengan katalisis mikroorganisme.

Salah satu limbah yang dapat dimanfaatkan adalah limbah buangan dari rumah pemotongan hewan yaitu limbah dari rumen sapi. Limbah rumen sapi tersebut mengandung materi organik yang masih dapat dimanfaatkan salah satunya sebagai substrat MFC untuk menghasilkan energi listrik. Menurut hasil penelitian Sitorus (2010), rangkaian tunggal MFC single chamber dengan memanfaatkan limbah cair menunjukkan bahwa air buangan rumen sapi memberikan beda potensial listrik paling besar diantara air buangan industri sawit dan tahu yaitu sebesar $810 \mathrm{mV}$.

Pada rangkaian tunggal MFC dihasilkan daya listrik yang cukup rendah sehingga diperlukan peningkatan peforma sistem MFC. Sistem Stack MFC merupakan salah satu cara untuk menghasilkan daya listrik yang lebih besar dibandingkan penelitian sebelumnya. Seperti yang diungkapkan Kristin (2012:9) Stack MFC merupakan rangkaian dari beberapa unit MFC baik dual chamber maupun single chamber yang dirangkai seri, paralel maupun campuran (seriparalel), tujuannya adalah untuk meningkatkan kapasitas daya yang diproduksi.

Teknologi pemanfaatan limbah ini sangat berpotensi untuk terus dikembangkan, karena menggunakan sumber alam serta ramah lingkungan sehingga dirasa sangat perlu untuk dikenalkan sejak dini kepada para generasi penerus, dalam hal ini adalah para siswa sekolah. Salah satu cara adalah dengan menggunakan MFC dalam pembelajaran fisika. Dari hasil wawancara kepada guru fisika di SMA Muhammadiyah 4 Kota Bengkulu diketahui bahwa nilai rata-rata ujian fisika kelas $\mathrm{X}$ pada sekolah tersebut masih tergolong rendah. Berdasarkan kenyataan tersebut, perlu diterapkan suatu model pembelajaran yang sesuai dan mampu meningkatkan hasil belajar fisika siswa.

Salah satu model pembelajaran yang memungkinkan mengembangkan keterampilan berpikir, kemandirian dan percaya diri siswa adalah model Problem Based learning (PBL). Berdasarkan hasil penelitian Rosmiati (2015) terdapat perbedaan hasil belajar antara siswa yang diajarkan menggunakan model PBL dengan siswa yang diajarkan menggunakan pembelajaran konvensional di kelas X SMAN 1 Kota Bengkulu. Penelitian mengenai pembelajaran menggunakan model PBL juga dilakukan oleh Suherianti et al (2018) dan didapatkan bahwa hasil belajar kognitif peserta didik mengalami peningkatan nilai rata-rata ketika menggunakan model Problem Based Learning (PBL). Menurut Arends dalam Tampubolon dan Hambali (2014), model PBL guru membawa masalah kehidupan nyata yang dekat dengan kehidupan siswa ke dalam pembelajaran. Hal ini membuat siswa tertantang untuk mencari solusi pemecahan masalah yang mereka hadapi tersebut. Sehingga pada akhirnya akan berpengaruh baik pada peningkatan pemahaman materi dan kemampuan berpikir ilmiah siswa dan siswa dapat menerapkan konsep yang telah diperolehnya selama proses pembelajaran.

Krisis energi listrik merupakan salah satu permasalah nyata yang dekat dengan kehidupan siswa. Salah satu dampak dari krisis energi listrik yang ikut dirasakan para siswa adalah dengan adanya pemadaman listrik secara bergiliran. Dengan mengorientasi siswa pada masalah tersebut pada awal pembelajaran model PBL diharapkan dapat meningkatkan motivasi siswa untuk belajar dan menemukan solusi dari masalah tersebut. Tidak hanya mengatasi krisis energi listrik tetapi juga mengatasi permasalahan 
limbah yaitu dengan memanfaatkan limbah rumen sapi menjadi substrat MFC untuk menghasilkan energi listrik.

\section{METODE PENELITIAN}

\section{Penelitian Sains}

Desain penelitian adalah eksperimen dengan tahapan sebagai berikut:

Persiapan alat dan bahan

Adapun alat dan bahan yang digunakan dalam penelitian ini adalah:

Tabel 1. Alat yang digunakan

\begin{tabular}{ll}
\hline No. & \multicolumn{1}{c}{ Alat } \\
\hline 1 & $\begin{array}{l}\text { Reaktor MFC terdiri atas : } \\
\text {-Toples plastik }\end{array}$ \\
& -Pipa U \\
2 & Multimeter Digital \\
3 & Amperermeter analog \\
4 & Kabel dan Jepit buaya \\
5 & Resistor 1 $\Omega$ dengan toleransi $\pm 5 \%$ \\
6 & Timbangan analitik \\
7 & Gelas beaker \\
8 & Gelas ukur \\
9 & Spatula kaca \\
10 & Pipet Ukur \\
11 & Pipet tetes \\
12 & Jangka sorong \\
\hline
\end{tabular}

Tabel 2. Bahan yang digunakan

\begin{tabular}{clc}
\hline No. & \multicolumn{1}{c}{ Alat } & Jumlah \\
\hline 1 & Batang karbon & 12 Buah \\
2 & Elektroda tembaga & 12 Buah \\
3 & Agar-agar & 1 Bungkus \\
4 & Garam dapur & 1 Sendok \\
5 & Aquadest & 0,5 Liter \\
6 & KMNO $_{4} 0,2 \mathrm{M}$ & 4,8 liter \\
7 & Amplas & 1 Lembar \\
8 & Alumnium foil & 1 Gulung \\
\hline
\end{tabular}

Membuat dan Menyusun Rangkaian Sistem Stack MFC

Jenis rangkaian pada penelitian ini berupa Dual Chamber MFC yang merujuk pada penelitian Hermawan, et al (2014). Masingmasing kompartemen bervolume $400 \mathrm{ml}$. Katoda (katolit) pada setiap sistem adalah larutan $\mathrm{KMNO}_{4}$ 0,2 $\mathrm{M}$ sedangkan Anoda (anolit) adalah limbah cair rumen sapi. Rangkaian tunggal dual chamber MFC digambarkan pada Gambar 1 dan 2.

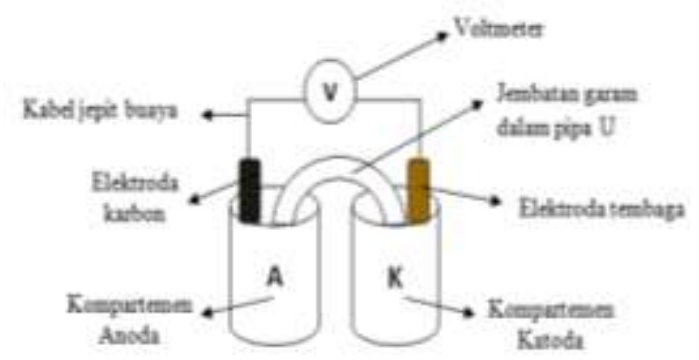

Gambar 1. Rangkaian tunggal dual chamber MFC untuk mengukur GGL

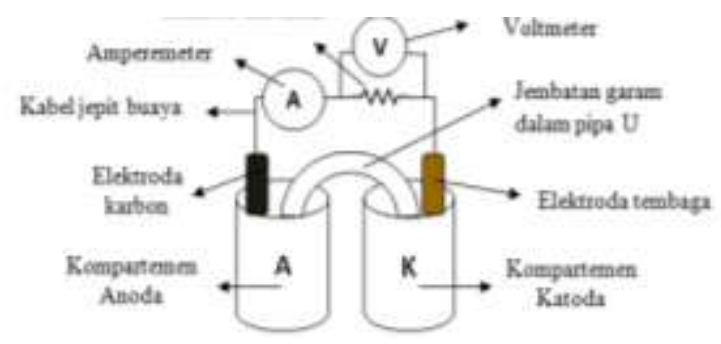

Gambar 2. Rangkaian tunggal dual chamber MFC untuk mengukur GGL

Tiga buah rangkaian tunggal dual chamber MFC dengan masing-masing kompartemen bervolume $400 \mathrm{ml}$ akan dirangkai dengan variasi sebagai berikut:

1) Rangkaian Seri

2) Rangkaian Paralel

3) Rangkaian Campuran Tipe 1

4) Rangkaian Campuran Tipe 2

\section{Sampel}

Sampel limbah rumen sapi diambil dari Rumah Pemotongan Hewan (RPH) milik Pemerintah Kota Bengkulu yang berlokasi di Kelurahan Padang Serai Kota Bengkulu

\section{Teknik Pengumpulan data}

Pengumpulan data dilakukan dengan cara pengukuran yang dilakukan setiap dua jam selama 96 jam dengan dua kali pengukuran yaitu pengukuran Gaya Gerak Listrik (GGL) dan mengukur beda potensial (V) dan kuat arus listrik (I). 


\section{Teknik Analisa Data}

Analisa data pada penelitian ini terdiri atas: (1) Analisis Perbedaan GGL dan (2) Analisis Perbedaan Daya Listrik per satuan luas Anoda. Menurut Kim (2009) jumlah luas permukaan anoda tersedia bagi mikroba untuk tumbuh dapat mempengaruhi jumlah daya yang dihasilkan. Banyak peneliti menggunakan luas permukaan anoda untuk menghitung daya persatuan luas dihitung dengan persamaan :

$$
P_{A}=\frac{\left(V_{M F C}\right)^{2}}{R_{\text {ext }} A_{A n}}
$$

$\mathrm{R}_{\text {eks }}$ sebesar $1 \Omega$ toleransi $5 \%$ dan $\mathrm{A}_{\text {an }}$ sebesar $15,4610^{-4} \mathrm{~m}^{2}$

\section{Penelitian Pendidikan}

\section{Desain Penelitian}

Penelitian ini menggunakan desain one group pretest-posttest design untuk dua kelas eksperimen. Disain penelitian dapat dilihat pada Tabel 3.

Tabel 3. Desain Penelitian Pendidikan

\begin{tabular}{|c|c|c|c|}
\hline Kelas & Pretest & Perlakuan & Posttest \\
\hline $\begin{array}{c}\text { Kelas } \\
\text { eksperimen 1 }\end{array}$ & $\mathrm{O}_{1}$ & $\mathrm{X}_{1}$ & $\mathrm{O}_{2}$ \\
\hline $\begin{array}{c}\text { Kelas } \\
\text { Eksperimen 2 }\end{array}$ & $\mathrm{O}_{3}$ & $\mathrm{X}_{2}$ & $\mathrm{O}_{4}$ \\
\hline
\end{tabular}

Keterangan :

$\mathrm{X}_{1}=$ Model pembelajaran PBL menggunakan media MFC

$\mathrm{X}_{2}=$ Model pembelajaran PBL menggunakan media kit listrik

$\mathrm{O}_{1}=$ skor pretest untuk kelas eksperimen 1

$\mathrm{O}_{2}=$ skor posttest untuk kelas eksperimen 1

$\mathrm{O}_{3}=$ skor pretest $\mathrm{untuk}$ kelas eksperimen 2

$\mathrm{O}_{4}=$ skor posttest untuk kelas eksperimen 2

$\mathrm{O}_{1}=\mathrm{O}_{3}$ (Penelitian dapat dilakukan jika Skor pretest antara Kelas eksperimen 1 dan kelas eksperimen 2 tidak berbeda secara signifikan).

\section{Populasi dan Sampel}

Populasi penelitian adalah seluruh siswa kelas X SMA Muhammadiyah 4 Kota Bengkulu semester II tahun ajaran 2015/2016 yang berjumlah 5 kelas. Sampel yang dipilih secara purposive pada penelitian ini adalah kelas X.1 dan X Unggul 2.

\section{Teknik Pengumpulan Data}

Teknik pengumulan data yang digunakan pada penelitian ini adalah tes. Tes dilaksanakan dua kali dalam satu kali pertemuan yaitu pretest (tes awal) dan posttest (tes akhir).

\section{Teknik Analisis Data}

Pengolahan dan analisis data yang dilakukan meliputi analisis deskriptif, analisis inferensial dan pengujian hipotesis. Pengujian hipotesis menggunakan Uji-t Dua Sampel Independen dikarenakan $\mathrm{n}_{1} \neq \mathrm{n}_{2}$ dan varian homogen. Menurut Sugiyono (2009), rumus uji-t dengan pooled varian untuk dua sampel independen sebagai berikut:

$$
\mathrm{t}=\frac{\overline{\mathrm{x}_{1}}-\overline{\mathrm{x}_{2}}}{\sqrt{\frac{\left(\mathrm{n}_{1}-1\right) \mathrm{s}_{1}^{2}+\left(\mathrm{n}_{1}-1\right) \mathrm{s}_{2}^{2}}{\mathrm{n}_{1}+\mathrm{n}_{2}-2}\left(\frac{1}{\mathrm{n}_{1}}+\frac{1}{\mathrm{n}_{2}}\right)}}
$$

Keterangan :

$\mathrm{t}=$ Nilai $\mathrm{t}$ hitung

$\overline{X_{1}}=$ Rata-rata skor kelompok 1

$\overline{X_{2}}=$ Rata-rata skor kelompok 2

$\mathrm{n}_{1} \quad=$ Jumlah sampel kelompok 1

$\mathrm{n}_{2} \quad$ = Jumlah sampel kelompok 2

$\mathrm{S}_{1}^{2}=$ Varian kelompok 1

$\mathrm{S}_{2}{ }^{2}=$ Varian kelompok 2

Jika harga $t_{\text {hitung }}>t_{\text {tabel }}$ pada taraf signifikan $95 \%$ dan derajat kebebasan $(\mathrm{dk})=\mathrm{n}_{1}$ $+\mathrm{n}_{2}-2$, maka terdapat perbedaan yang signifikan. Pengujian hipotesis dilakukan dengan menggunakan Microsoft Exel 2007 dengan taraf signifikan $95 \%$. 


\section{HASIL DAN PEMBAHASAN}

\section{Pengukuran dan Perbandingan GGL pada Rangkaian MFC}

Besar GGL diperoleh setelah menghubungkan secara langsung multimeter dengan kedua kabel baik dari anoda maupun katoda tanpa menggunakan resistor eksternal, seperti terlihat pada Gambar 3.

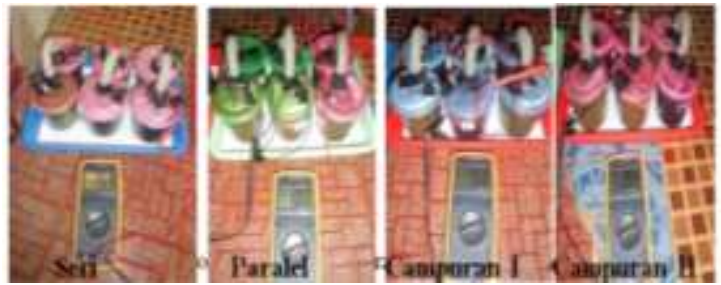

Gambar 3. Dokumentasi Pengukuran GGL Pada Rangkaian MFC

Pengukuran dilakukan setiap 2 jam selama 96 jam (4 hari). Grafik hasil pengukuran GGL pada setiap rangkaian MFC dapat dilihat pada Gambar 4.

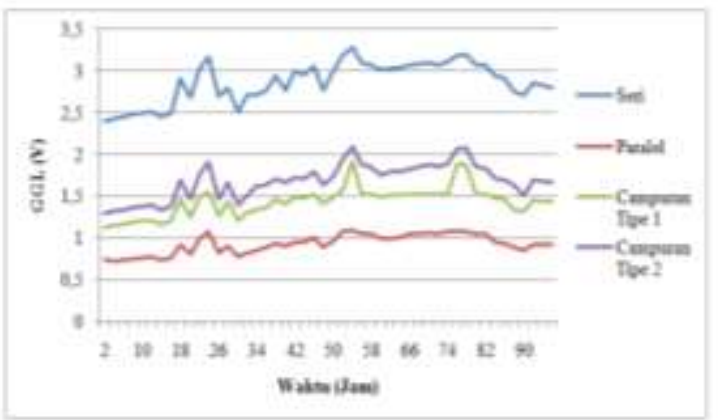

Gambar 4. Grafik Hasil Pengukuran GGL Pada Rangkaian MFC

Berdasarkan hasil pengukuran Nilai GGL berfluktuasi di tiap waktu pengukuran. Hal ini terkait pula dengan aktivitas metabolisme mikroba yang terdapat pada limbah cair. Dalam aktivitas katabolisme, sejumlah energi dihasilkan saat senyawa kompleks dipecah menjadi senyawa sederhana. Sebaliknya, sejumlah energi digunakan saat senyawa sederhana disintesis menjadi senyawa kompleks. Kedua jenis metabolisme ini terjadi secara simultan. Pada waktu tertentu secara umum selisih dari total energi yang dihasilkan dan yang digunakan dapat meningkat atau menurun, bergantung pada reaksi yang berlangsung.

Rangkaian seri memiliki nilai GGL terbesar karena besar GGL total merupakan jumlah dari semua GGL dari masing-masing rangkaian tunggal dual chamber MFC. Sebaliknya pada rangkaian paralel nilai GGL total sama dengan nilai GGL dari satu rangkaian tunggal MFC sehingga nilai GGL terkecil diperoleh pada rangkaian paralel. Pada rangkaian campuran tipe 2 terdapat dua rangkaian tunggal yang diparalelkan lalu diserikan dengan satu rangkaian tunggal lainnya. Nilai GGL yang dihasilkan pada rangkaian campuran tipe 2 sama dengan jumlah 2 rangkaian tunggal MFC. Sedangkan pada rangkaian campuran tipe 1 . Terdapat dua rangkaian tunggal yang diserikan lalu diparalelkan dengan satu rangkaian tunggal lainnya. Nilai GGL pada rangkaian campuran tipe 1 sama dengan 1,5 kali dari rangkaian tunggal MFC. Sehingga perbandingan besar GGL yang dihasilkan antara disain rangkaian MFC tipe seri, paralel, campuran tipe 1 dan campuran tipe 2 adalah $3: 1: 1,5: 2$ yang mana besar GGL maksimum diperoleh pada rangkaian seri sebesar 3,29 V.

\section{Perbandingan Daya Listrik Per Satuan Luas Anoda}

Hasil perhitungan daya listrik per satuan luas permukaan anoda disajikan dalam bentuk grafik yang tersaji pada Gambar 5.

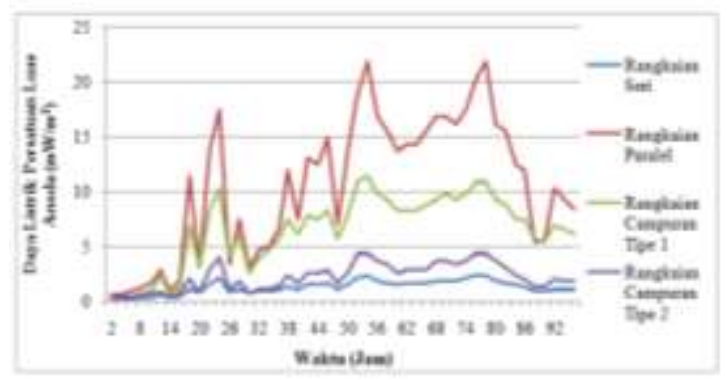

Gambar 5. Grafik Hasil Perhitungan Daya Listrik Per Satuan Luas Permukaan Anoda Pada Rangkaian MFC

Berdasarkan Gambar 5 terlihat bahwa nilai daya listrik per satuan luas anoda 
maksimum diperoleh pada rangkaian paralel sebesar 21,76 $\mathrm{mW} / \mathrm{m}^{2}$ sedangkan nilai minimum diperoleh pada rangkaian seri sebesar $0,06 \mathrm{~mW} / \mathrm{m}^{2}$.

Terdapat perbedaan besar daya listrik per satuan luas permukaan anoda (Pa) yang dihasilkan antara disain rangkaian MFC tipe seri, paralel, campuran tipe 1 dan campuran tipe 2 dengan perbandingan $1: 10: 6: 2$.

\section{Penelitian pendidikan}

Penelitian dilakukan untuk melihat ada tidaknya perbedaan hasil belajar kognitif siswa antara kelas eksperimen 1 dan kelas eksperimen 2. Data yang akan diuji hipotesis adalah rata-rata skor posttest siswa yang mendapat pembelajaran model PBL menggunakan media MFC (kelas eksperimen 1) dan siswa yang mendapat pembelajaran model PBL dengan menggunakan media kit listrik (kelas eksperimen 2).

Data rata-rata skor posttest siswa pada kelas eksperimen 1 dan kelas eksperimen 2 telah diketahui berdistribusi normal dan memiliki varian yang homogen, sehingga dapat dilakukan statistik parametris, selanjutnya dilakukan uji hipotesis rata-rata posttest siswa dengan melakukan uji-t dua sampel independen. Sebelum perhitungan perbedaan rata-rata skor posttest dilakukan terlebih dahulu dilakukan perhitungan perbedaan rata-rata kemampuan awal siswa. Kemampuan awal siswa sebelum mengikuti pembelajaran diukur dengan menggunakan rata-rata skor pretest. Tabel 4 berikut ini merupakan hasil analisis uji-t dua sampel independen.

Tabel 4 Hasil Uji-t Hasil Belajar Kognitif

\begin{tabular}{|c|c|c|c|c|c|}
\hline Hasil & Kelas & $\mathrm{N}$ & $t_{\text {matas }}$ & $t_{a b e l}$ & Kesimpulan \\
\hline \multirow[t]{2}{*}{ Pretest } & Eksperimen 1 & 31 & \multirow[t]{2}{*}{0,946} & \multirow[t]{2}{*}{2,001} & \multirow{2}{*}{$\begin{array}{l}\text { Tidak Berbeda } \\
\text { Signifikan }\end{array}$} \\
\hline & Eksperimen 2 & 30 & & & \\
\hline \multirow[t]{2}{*}{ Posttest } & Eksperimen 1 & 31 & \multirow[t]{2}{*}{2,739} & \multirow[t]{2}{*}{2,001} & \multirow{2}{*}{$\begin{array}{l}\text { Berbeda } \\
\text { Signifikan }\end{array}$} \\
\hline & Eksperimen 2 & 30 & & & \\
\hline
\end{tabular}

Berdasarkan hasil pretest yang didukung oleh uji perbedaan rata-rata antara pretest kelas eksperimen 1 dan eksperimen 2, menunjukkan bahwa tidak terdapat perbedaan yang signifikan pada kemampuan awal kedua kelas yang mana $t_{\text {hitung }} 0,946<t_{\text {tabel }} 2,001$ untuk taraf signifikan
95\%. Pengujian perbedaan rata-rata rata-rata skor posttest dengan uji-t dua sampel independen menunjukkan bahwa terdapat perbedaan yang signifikan pada hasil belajar siswa kedua kelas yang mana diperoleh $t_{\text {hitung }}$ $2,739>t_{\text {tabel }} 2,001$ untuk taraf signifikan $95 \%$. Kelas eksperimen 1 yang menggunakan media MFC mempunyai rata-rata skor posttest yang lebih tinggi dibandingkan kelas eksperimen 2 yang menggunakan media Kit Listrik. Skor $\mathrm{t}_{\text {hitung }}$ ini jatuh pada daerah penolakan hipotesis nol $\left(\mathrm{H}_{0}\right)$. Dengan demikian dapat disimpulkan, kelas eksperimen 1 yang mengikuti pembelajaran dengan model PBL menggunakan media MFC memiliki hasil belajar yang lebih tinggi dibandingkan kelas eksperimen 2 yang mengikuti pembelajaran model PBL menggunakan media Kit Listrik.

Hal ini disebabkan karena media MFC membawa masalah kehidupan yang lebih nyata dibandingkan dengan media Kit Listrik. Rangkaian MFC menggali rasa ingin tahu siswa akan kemampuan limbah dalam menghasilkan listrik dimana selama ini mereka hanya mengetahui bahwa listrik diolah oleh PLN dengan sumber tenaga diperoleh dari batu bara, minyak bumi, ataupun dari PLTA yang pembuatannya membutuhkan dana dan waktu yang lama.

Pada pertemuan pertama, rasa ingin tahu siswa langsung dibangkitkan dengan timbulnya bau dari limbah rumen sapi. Para siswa kebingungan melihat rangkaian yang ada didepannya dengan rasa ingin tahu dari manakah bau itu berasal. Saat proses pembelajaran sub konsep besaran listrik dan hukum ohm, para siswa dikelas eksperimen 1 lebih memahami aliran elektron dari kutub negatif ke kutub positif yang tak lain adalah kuat arus listrik. Berbeda dengan siswa kelas eksperimen 2 yang kesulitan memahami aliran arus listrik karena resistor harus diletakkan dipapan rangkaian, sedangkan pada kelas eksperimen 1, kabel langsung dihubungkan melalui kabel tanpa perlu menggunaan jembatan penghubung seperti pada kit listrik. Hal ini nampak pada rendahnya skor rata-rata posttest kelas eksperimen 2 dibandingkan dengan kelas eksperimen 1 seperti yang nampak pada Gambar 6. 


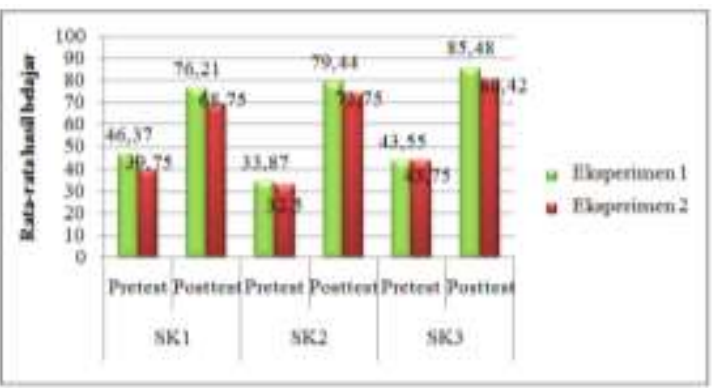

Gambar 6. Grafik Perbandingan Rata-rata skor Hasil Belajar Untuk Setiap Subkonsep Antara Kelas Eksperimen 1 dan 2

\section{Keterangan:}

$\mathrm{SK}_{1}=$ besaran listrik dan hukum ohm; $\mathrm{SK}_{2}=$ susunan hambatan dan hukum kirchoff; $\mathrm{SK}_{3}=$ penerapan listrik AC dan DC dalam kehidupan sehari-hari

Pada pertemuan kedua mengenai susunan rangkaian hambatan dan hukum kirchhoof. Skor rata-rata pretest pada kedua kelas mengalami peurunan karena diebabkan oleh kerumitan materi susunan resistor, dimana pada pertemuan sebelumnnya hanya menggunakan 1 resisor. Pada pertemuan ini kelas eksperimen 1 yang menggunakan rangkaian MFC kembali dimudahkan pada pemahaman dalam mengukur kuat arus dan tegangan. Amperemeter harus terpasang seri dengan resistor saat mengukur kuat arus listrik, dan sebaliknya voltmeter harus terpasang paralel. Pada kelas eksperimen 2 siswa kesulitan dalam menentukkan titik manakah mereka harus mencolokkan kabel. Hal ini nampak kembali pada skor posttest siswa kelas eksperimen 1 yang lebih tinggi dibandingkan kelas eksperimen 2.

Pertemuan ketiga membahas konsep penerapan listrik AC dan DC dalam kehidupan sehari-hari. Pada kelas ekeperimen 2 listrik DC dicontohkan dengan baterai sedangkan pada kelas eksperimen 1, listrik DC dicontohkan dengan baterai dan rangkaian MFC. Siswa pada kelas ekesperimen 2 yang menggunakan rangkaian MFC dapat membedakan antara baterai dan MFC, walaupun keduanya merupakan sumber listrik DC tetapi kutub positif dan negatifnya berbeda. Anoda dan Katodanya pun berbeda. Sedangkan kelas eksperimen 2 hanya dapat mempelajari tentang prinsip kerja dari baterai. Penggunaan media MFC sebagai media pembelajaran konsep listrik dinamis terbukti dapat meningkatkan hasil belajar kognitif siswa. Hal ini dikarenakan media MFC meudahkan siswa dalam memahami susunan rangkaian listrik, aliran arus listrik,dan memahami cara merangkai resistor ataupun alat ukur lisrik secara seri dan paralel.

\section{KESIMPULAN}

Dari hasil penelitian yang telah dilakukan dapat disimpulkan bahwa terdapat perbedaan besar Gaya Gerak Listrik (GGL) yang dihasilkan antara disain rangkaian MFC tipe seri, paralel, campuran tipe 1 dan campuran tipe 2 dengan perbandingan $3: 1: 1,5: 2$ yang mana besar GGL maksimum diperoleh pada rangkaian seri sebesar 3,29 V. selain itu juga terdapat perbedaan besar daya listrik per satuan luas permukaan anoda $(\mathrm{Pa})$ yang dihasilkan antara disain rangkaian MFC tipe seri, paralel, campuran tipe 1 dan campuran tipe 2 dengan perbandingan $1: 10: 6: 2$ yang mana besar $\mathrm{Pa}$ maksimum dihasilkan pada rangkaian paralel sebesar $21,76 \mathrm{~mW} / \mathrm{m}^{2}$. Terdapat perbedaan hasil belajar yang signifikan antara pembelajaran model PBL menggunakan media MFC dengan pembelajaran model PBL menggunakan media kit listrik pada konsep listrik dinamis di SMA Muhammadiyah 4 Kota Bengkulu dengan hasil analisis uji-t dua sampel independen dari skor rata-rata posttest diperoleh $\mathrm{t}_{\text {hitung }} 2,739>\mathrm{t}_{\text {tabel }}$ 2,001 untuk taraf signifikan $95 \%$.

\section{DAFTAR PUSTAKA}

Hermawan, K.V., Djaenudin dan M. Rangga Sururi. 2014. Pengolahan air limbah industri tahu menggunakan sistem double chamber microbial fuel cell. Bandung: Jurnal Online ITENAS. No.1, Vol. 2.

Kim, M.H. 2009. An Analysis of Anaerobic Dual-Anode Chambered Microbial Fuel Cell (MFC) Performance. [Tesis]. Knoxville: Universitas Tennessee.

Kristin, E. 2012. Produksi Energi Listrik melalui Microbial Fuel Cell menggunakan 
limbah industri tempe. [Skripsi]. Jakarta: Universitas Indonesia.

Rosmiati. 2015. Pengaruh Komposisi Serat Pinang Terhadap Sifat Fisis Dan Mekanisme Papan Gipsum Dan Implementasinya Pada Uji Beda Hasil Belajar Model Problem Based Learning Dengan Model Konvensional Kelas X SMAN 1 Kota Bengkulu. [Tesis]. Bengkulu: Universitas Bengkulu.

Sitorus, B. 2010. Diversifikasi sumber energi terbarukan melalui penggunaan air buangan dalam sel elektrokimia berbasis mikroba. Jurnal ELKHA, 2(1).

Sugiyono. 2009. Metode Penelitian Pendidikan. Bandung: Alfabeta.
Suherianti, S., Mayub, A., \& Farid, M. 2018. Potensi Rawan Banjir Kecamatan Muara Bangkahulu Sebagai Penunjang Pembelajaran Materi Pemanasan Global Di SMPN 11 Kota Bengkulu. Pendipa Journal Of Science Education, 2(1).

Tampubolon,T. dan Taufik Hambali. 2014. Pengaruh model pembelajaran Probem Based Learning terhadap hasil belajar siswa pada materi pokok listrik dinamis kelas X MAS 'Tadurrahman Stabat. Medan: Jurnal Inpafi. 2(3).

Zhang, Y. 2012. Energy recovery from waste streams with microbial fuel cell (MFC)based technologies. [Tesis]. Denmark: Universitas Teknik Denmark. 